og ekspert på cyberspace. Mangeårig kompanjong Marino er støtt ut i kulden. Scarpetta tilkalles da politiet har fått inn en forvirret mann iført fotlenke og håndjern, som melder om at hans venninne er drept. Han blir innlagt på psykiatrisk sykehus, hvor han meddeler at den eneste han vil kommunisere med, er den berømte rettsmedisineren. Hans venninne har angivelig mailet med Scarpetta, eller noen som utgir seg for å være henne. Etter hvert forstår man at også Scarpetta er i faresonen, og at en morder går løs.

Som tidligere fan av Kay Scarpetta var det forstemmende å lese denne boken. Etter 80 sider aner man knapt hva plottet egentlig dreier seg om, etter 250 sider sitter man med den samme følelsen som da man, som student, pugget muskel- og skjelettapparatet, nemlig at bokens 471 sider fortoner seg uoverkommelige, og at man skulle ønske man var igjennom. Jeg opplever karakterene som endimensjonale. Historien eier ikke driv, og i alle fall ikke krimhistoriens forventede utviklingskurve frem mot klimaks. Tvert imot hopper fortellingen hit og dit uten mål og mening. Boken inneholder side opp og side ned med endeløst prat og ørkesløse diskusjoner som ikke tilfører historien noe nytt. Språkblødmer er det flere av, som «Det var egentlig en lykke at Rivjernet ville ha grudd seg til juleferien om hun hadde hatt mulighet til å nyte den, for den var intet annet enn et tomt skip som førte henne fra det ene året og inn i det neste og minnet henne på hva hun ikke hadde og hva som ikke lå foran henne, og at biologien var nådeløs og spilte henne stygge puss». På samme måte er Scarpettas og Wesleys funderinger rundt eget kjærlighetsliv gitt for stor plass. Midt $i$ handlingen begir de seg plutselig ut på endeløse tankeflukter av typen «Jo lenger han bladde seg bakover gjennom livets sider [...], desto mer forbløffet var han blitt over flere ting, ikke minst over Scarpettas uimottakelighet. Hun hadde ærlig talt ikke skjønt hvordan han hadde det og hadde vært mye mer opptatt av det hun selv hadde følt. Det var i hvert fall det hun hadde sagt da hun innrømmet at de gangene hun hadde sett ham med dokumentmappe på fanget, så hadde det, med få unntak, betydd at han skjulte en ereksjon». Også Lucys kjærlighetsliv får rikelig plass i den siste delen. Slikt blir det sider av, men ikke innhold. Leseren blir utmattet, og historien kjører av sporet. Opprullingen skjer over de siste 50 sidene, men da er det forlengst knekkende likegyldig hvem som er morderen.

Cornwell kan det meste om dataverdenens og rettsmedisinens mange tekniske nyvinninger. Men igjen, det øses på, og det blir for mye. Aktørenes tanker og følelser forklares også ned til minste detalj. Ingenting er overlatt til leserens fantasi, med langtekkelighet som resultat.

For undertegnede oppleves det som om Scarpetta her er i fritt fall. Boken vitner om en uinspirert forfatter på tomgang. Jeg er fristet til å tro at forfatterens redaktør har sendt manus uredigert rett $i$ trykken, i forvissning om at både forfatterens og hovedpersonens godt etablerte navn vil selge. Det er synd for Patricia Cornwell, som kan uendelig mye bedre.

Jorun Thørring Loennechen

Trondheim

\section{Etikk i helse- og sosialtjeneste}

Henriette Sinding Aasen, Rune Halvorsen, António Barbosa da Silva, red.

Human rights, dignity and autonomy in health care and social services: Nordic perspectives 221 s, ill. Mortsel: Intersentia Publishing, 2009. Pris EUR 54

ISBN 978-90-5095-877-6

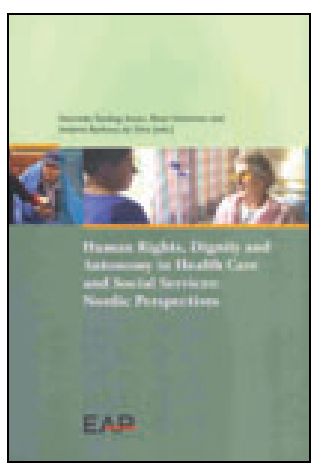

Forfatterne av denne boken argumenterer for humanistisk etikk i nordisk helse- og sosialtjeneste. Den er redigert av juristen Henriette Sinding Aasen, samfunnsviteren Rune Halvorsen og filosofen António Barbosa da Silva.

Bakgrunnen er menneskerettighetene, og spørsmålet er: Hva er det etiske og juridiske grunnlaget for å beskytte menneskerettighetene til mennesker hvor autonomien står på spill; barn, personer med kognitiv funksjonsnedsettelse, med psykisk lidelse eller med kroppslige funksjonshemninger? Åtte forskere fra de nordiske landene svarer.

I de to innledende kapitlene gjør Barbosa da Silva og Aasen grundig rede for det humanistiske menneskesynet og menneskeverdprinsippet (post-kantiansk humanisme). Menneskeverdet er den mest grunnleggende verdien, og den er lik for alle mennesker. Autonomien varierer hos mennesker, men det gjør ikke verdighet og integritet. Derfor er menneskets verdighet, ikke autonomi, det ypperste grunnlaget for helsetjenesteetikk, lov og menneskerettigheter. Det ikke-humanistiske menneskesynet og den ikke-humanistiske etikken kritiseres. Denne analysen er viktig og opplysende fordi den viser at sentrale ord i etikken, som verdighet, har meget forskjellig betydning i humanistisk og ikkehumanistisk etikk. Mens man i humanistisk etikk hevder at verdigheten er lik for alle, hevder man i ikke-humanistisk etikk at den ikke er det. Den anses avhengig av hva personen har ytt, av kompetanse, samfunnsposisjon eller moralsk verdi.
Tekstens overordnede idé er at det humanistiske menneskeverdprinsippet beskyttes av et knippe mer spesifikke prinsipper. Integritetsprinsippet (respekt for integritet, sårbarhet og identitet) forsvares som overordnet. De andre prinsippene er ikke å gjøre skade, autonomi (informert samtykke, taushetsplikt, politisk frihet), velgjørenhet (inkludert ekte paternalisme) og rettferdighet. Når autonomiprinsippet ikke kan brukes, gjelder det i hver enkelt situasjon på en konkret og nyansert måte å finne den rette balansen mellom de andre prinsippene. Pasientens/brukerens egen oppfatning bør så langt som mulig tas med $i$ vurderinger. Forfatterne viser også sammenhenger mellom etikk og juss.

I egne kapitler tar forfatterne for seg bruken av det humanistiske menneskeverdprinsippet: barns rett til å delta i avgjørelser som angår dem selv (Kirsten Sandberg og Marit Skivenes), forsvar av menneskeverd hos mennesker med kognitive svikttilstander (Aasen) og når tvang enkelte ganger bør brukes i den psykiske helsetjenesten (Mette Hartlev). En svakhet ved den nordiske politikken, for mennesker med funksjonshemninger med hensyn til reelle muligheter til å arbeide, belyses (Halvorsen og Bjørn Hvinden). Forskningsetiske spørsmål når menneskeverd kommer $\mathrm{i}$ konflikt med forskningsverdier, diskuteres (Barbosa da Silva og Salla Lötjönen) også.

For etisk interesserte er boken tankevekkende og viktig å bruke tid og krefter på. Innen helsetjeneste og NAV vil jeg si at målgruppen er klinikere, veiledere, forskere, ledere og planleggere som har forkunnskaper om etikk.

\section{Hans Magnus Solli}

Forskningsenheten

Psykiatrien i Vestfold

Tønsberg 